\title{
The Effect of Temperature Variation on the Yield Edible Film of Canna Starch (Canna edulis Kerr) Modified by Aloe Vera (Aloe vera L) with Addition of Purple Cabbage (Brassica oleracea) Anthocyanin Pigment as Bioindicator
}

\author{
Meida Dwi Nugraheni1, Dwiarni Fitri Wulansari", Endaruji Sedyadi, Irwan Nugraha, Ika Nugraheni Ari \\ Martiwi \\ Chemistry Department, Faculty of Science and Technology, UIN Sunan Kalijaga Yogyakarta \\ Jl. Marsda Adisucipto, No. 1 Yogyakarta 55281, Indonesia. Telp. (0274) 519739 Fax (0274) 540971 \\ Email: dwiarnisari@gmail.com
}

\begin{abstract}
Edible films are made from canna tuber starch, glycerol, aloe vera gel, and addition of purple cabbage extract (Brassica oleracea) aimed to determine the effect of temperature variation on the results of edible film synthesis and anthocyanin effectiveness of purple cabbage as a $\mathrm{pH}$ indicator. The stages in this study include isolation of canna tuber starch, extraction of purple cabbage, making aloe vera gel, determination of anthocyanin extract proportions, synthesis of edible films with varied temperatures, and characterization of edible film results. Optimal composition of cabbage extract as a $\mathrm{pH}$ bio-indicator is used for synthesis of edible film with temperature variations between $75-90^{\circ} \mathrm{C}$ and elongation of $26.6 \%$ and WVTR value of $4.750 \mathrm{~g} / \mathrm{m}^{2} \mathrm{~h}$ at $85^{\circ} \mathrm{C}$.
\end{abstract}

Keyword: Aloe vera, Canna starch, Edible films, Glycerol, pH bioindicator, Purple cabbage extract

\section{INTRODUCTION}

Plastics as food packaging is often used because it has several advantage, such as flexible, easy to form, transparent, not easily broken, and the price relatively cheap. On the other hand, plastics also have weakness, such as not being heat-resistant, easily torn, and can cause contamination through the monomer, as well as difficult nature of being degraded in the soil (Ningwulan, 2012). Some methods often used reduce the amount of waste, namely burning plastic waste, recycling, and making edible film.

Edible films are film-shaped packaging, thin sheets made from edible ingredients and widely used as coating for frozen meat product, semi-wet foods, confentionary product, frozen chicken, seafood product, sausage, fruits, and medicines especially capsule coating (Krochta, 1994).

The advantages of using edible films for food packaging, which can inhibit the decline in food quality, low cost, reduce packaging waste, provide food protection by maintaining the aroma and appearance, prevent contamination, and prevent loss of food quality due to mass transfer (Skurtys, et al. 2009).

The process of making edible films starts the dissolution of the basic ingredients in the form of proteins, polysaccharides, lipids, or composites, then adding plasticizier. The mixture is then heated at a temperature of $55-70^{\circ} \mathrm{C}$ for 15 minutes. The film is then cast (casting) by pouring the mixture on the surface af a slippery polyethylene sheet. The source of polysaccharide is usually obtained from tubers, one of which is canna bulbs (Cana edulis Kerr).
Canna bulbs (Canna edulis Kerr, Cannaceae trible) have a higher starch content (reaching 30-40\%) compared to sweet potatoes (only about 20\%). Besides that canna tuber starch is edible and the amylose content is quite high $(32.53 \%$ on a dry basis) with optimal conditions the Canna starch concentration is $2 \%$ (b/v) (Wijoyo, 2004). Making edible films from canna starch with the addition of Aloe Vera just entered the synthesis stage with various concentrartions.

Edible films produced from the synthesis still has chemical and physical properties that need to be improved, so that it is expected that this synthesis with temperature variations can be done to determine the effect of temperature on the physical and chemical properties of edible films and can obtain the best results compared to existing results. The addition of anthocyanin pigment from Purple Cabbage is an innovation in making this edible film which can be used as a bioindicator of $\mathrm{pH}$ edible film, so that later it can give an indication of the quality of a package food. This study aims to determine the effect of temperature variation on the results of synthesis of edible films and the effectiveness of anthocyanins from purple cabbage as a bio-indicator of $\mathrm{pH}$.

\section{MATERIALS AND METHODS}

The ingredients used were Canna (Canna edulis Kerr) which was obtained from Ngreyung, Pucung, Girisubo, Gunungkidul, Yogyakarta, Aloe Vera and Brassica oleracea obtained from Hypermart Lippo Mall 
Yogyakarta, glycerol pa, distilled water,and $96 \%$ $\mathrm{H} 2 \mathrm{SO} 4$ brand Aldrick

The tools used to make edible films are grouped into three, the devices that use electricity, tools that do not use electricity, and tools used for analysis. Tools that use electricity include: hot plate (cimarec), oven (Haraeus UT 6120), blender, and analytical balance (Ohaus Advemturer). Tools that do not use electricity include: a set of glassware, suctions balls, thermometers, glass measuring $13 \mathrm{~cm} \mathrm{x} 13 \mathrm{~cm}$, knives, magnetic stirrer, filter paper, tissue, silica gel, and porcelain exchange rate. Finally, the tools used for analysis include: Fourier-Transform Infrared Spectroscopy (FTIR) instruments and Test Instruments for Strenghth and Tensile Strenght.

\section{Canna Starch Extraction}

Canna starch extraction was carried out which then the filtrate in the form of suspension was poured and deposited for one night. Deposits or starches obtained are then dried using an oven.

\section{Making Aloe Vera Gel}

Making aloe vera gel is done by cutting $5 \mathrm{~cm}$ aloe vera and peeling. Steam blancing is carried out at $70^{\circ} \mathrm{C}$ for 3 minutes and drained to blender so that it gets a smooth aloe gel.

\section{Anthocyanin Pigment Extraction in Purple Cabbage (Brassica oleracea)}

Purple cabbage as a bio-indicator of $\mathrm{pH}$ is blended and distilled water is added in a ratio 1:5 then heated with simmer technique, filtered and filtered into a closed container and stored in a refrigerator.

Optimization of Anthocyanin Extract in Edible Film Optimization of anthocyanin extract in edible films is done to determine the best proportion that will be applied to edible films in the process of further temperature variation synthesis. Edible film was synthesized by mixing the proportion of $6 \%$ canna tuber starch with $3 \%$ aloe vera, added with glycerol and extract the added with volume variations and added with distilled water to a volume of $100 \mathrm{ml}$. The mixture is heated and stirred for 30 minutes with a temperature of $75^{\circ} \mathrm{C}$. The suspension is cooled and stirred again, then the filtrate is printed. The film suspension is dried at $60^{\circ} \mathrm{C}$ for $2.5-3$ hours. Dry edible is then cooled at room temperature so that the edible film is easily removed. The result of edible films with a variety of anthocyanin extracts were then tested for their sensitivity to acids using the $\mathrm{pH}$ of $\mathrm{H} 2 \mathrm{SO} 4$.

\section{Making Edible Film}

Making edible film was carried out with a proportion if $6 \%$ canna tuber starch and 3\% aloe vera and added $15 \%$ glycerol (total) of the weight of the mixture of aloe vera gel and flour added. The mixture was added with distilled water and anthocyanin extract from purple cabbage, then heated and continued to stir for 30 minutes at the temperature variation of $75^{\circ} \mathrm{C}$ to $90^{\circ} \mathrm{C}$ at $5^{\circ} \mathrm{C}$ intervals.

The suspension was cooled and stirred again, then printed and dried at $60^{\circ} \mathrm{C}$ for 2.5 hours. Edible that has been finished is cooled at room temperature for approximately 24 hours to be easily removed.

The results of edible films with various temperature variations are then tested for physics and chemistry. Physical tests include, thickness test, tensile strength, and elongation. Chemical tests, including tests of water vapor transmission rate, water content, functional groups, and the effectiveness of $\mathrm{pH}$ bio-indicators.

\section{Data Analysis}

Data analysis techniques carried out include analysis of the physical and chemical properties of edible films produced. Physical analysis is carried out using Imada Measurement Instruments. Chemical properties analysis using FTIR instruments, where the instruments produces data in the form of transmittance and functional group spectra.

\section{RESULTS AND DISCUSSION}

The principle of starch extraction is based on the nature of starch granules which are not soluble in water. The separation process is the deposition of starch in water which is then separated and the starch is dried using an oven (Kusnandar, 2010 in Kholich, 2012).

\section{Canna Starch Extraction}

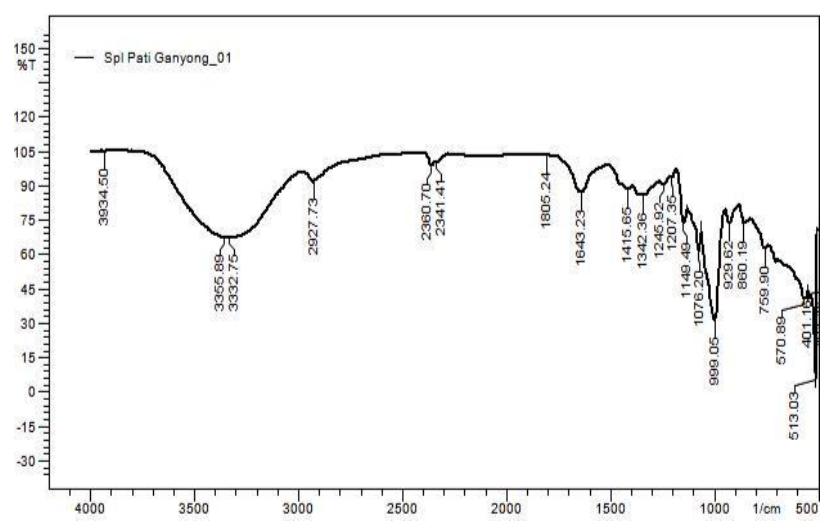

Figure 1. Starch Spectrum FT-IR Spectrum Canna.

The starch extraction process produces fine, white, and not hygroscopic starch powder. The yield of starch extraction, which is $8 \%$ of 500 grams of canna bulbs and it was found that canna tuber starch has absorption bands that are not much different from othe starches. Identification of functional groups is carried out at wave number $400-4000 \mathrm{~cm}^{-1}$. The spectrum of canna starch showed a wide uptake in the area $3355.89 \mathrm{~cm}^{-1}$ indicating the presence of an $\mathrm{O}-\mathrm{H}$ group. 
Uptake of $2927.73 \mathrm{~cm}^{-1}$ indicates the presence of a $\mathrm{C}-\mathrm{H}$ stretching group. In addition, the presence of uptake in the area of 1342.36 indicates the presence of $\mathrm{CH} 2$ groups. Absorption at wave numbers $1805.24 \mathrm{~cm}$ ${ }^{1}$ and $1643.23 \mathrm{~cm}-1$ indicates the presence of carbonyl groups, $\mathrm{C}=\mathrm{O}$. Absorption between $1415.65 \mathrm{~cm}^{-1}$ to $759.90 \mathrm{~cm}-1$ indicates the presence of $\mathrm{C}-\mathrm{C}$ groups. Uptake in the area of $1149.49 \mathrm{~cm}^{-1}$ indicates the presence of $\mathrm{C}-\mathrm{O}$ groups. While the presence of ether groups, C-O-C is shown in absorption between 1300 to $1000 \mathrm{~cm}-1$ (Sastrohamidjojo, 2013).

\section{Purple Cabbage Anthocyanin Extraction}

Extraction of purple or red cabbage can be done by simmer method. This method will produce extracts in a relatively faster time, so that it can be directly applied. Comparison of purple cabbage with solvent, which is 1:5 (b/v) which is intended to obtain anthocyanin extract which can be used directly as a pH bioindicator in the synthesis of edible film.

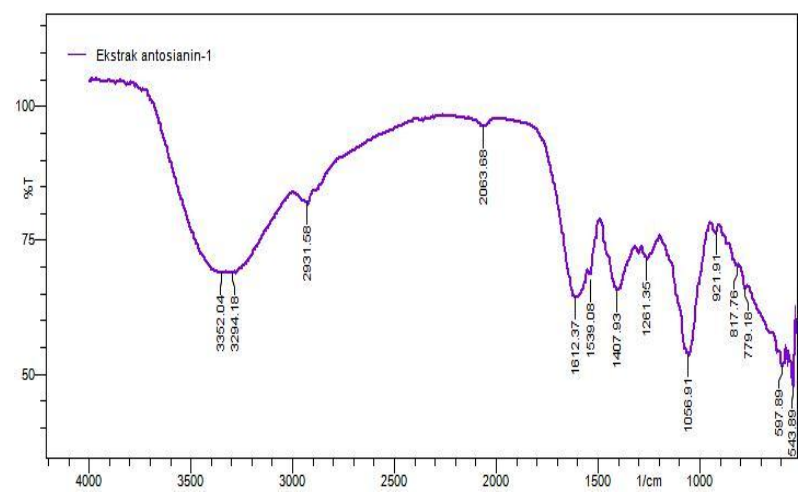

Figure 2. Purple cabbage anthocyanin test spectrum.

Absorption bands obtained between purple sweet potato anthocyanins and purple cabbage are not much different, because similar patterns are found between the two at each absorption of wave numbers. The results obtained from purple cabbage extract showed absorption at wave number $3352.05 \mathrm{~cm}^{-1}$ indicating the presence of $\mathrm{OH}$ group, then wave number absorption of $1612.37 \mathrm{~cm}^{-1}$ which showed the presence of aromatic $\mathrm{C}=\mathrm{C}$ group and the presence of alcohol $\mathrm{CO}$ groups in numbers wave $1056.91 \mathrm{~cm}^{-1}$.

Damayanti (2014) also identified anthocyanins from purple sweet potatoes using FT-IR. The infrared absorption pattern in figure 2 has similarities with the purple sweet potato anthocyanin spectrum absorption pattern.

Absorption bands obtained between purple sweet potato anthocyanins and purple cabbage are not much different, because similar patterns are found between the two at each absorption of wave numbers. Identification of uptake at certain wave number points has indicated the presence of anthocyanin compounds in purple cabbage extract that has been produced.

\section{Making Aloe Vera Gel}

Making and utilizing aloe vera gel refers to the research that has been carried out by Afriyah et al., (2015). The first step is sorting and washing from impurities. Aloe vera is then cut to a length of $5 \mathrm{~cm}$ and peeled so that aloe vera meat is produced. Steam blanching was carried out at $70^{\circ} \mathrm{C}$ for 3 minutes and drained. Aloe vera is then destroyed using a wet blender.

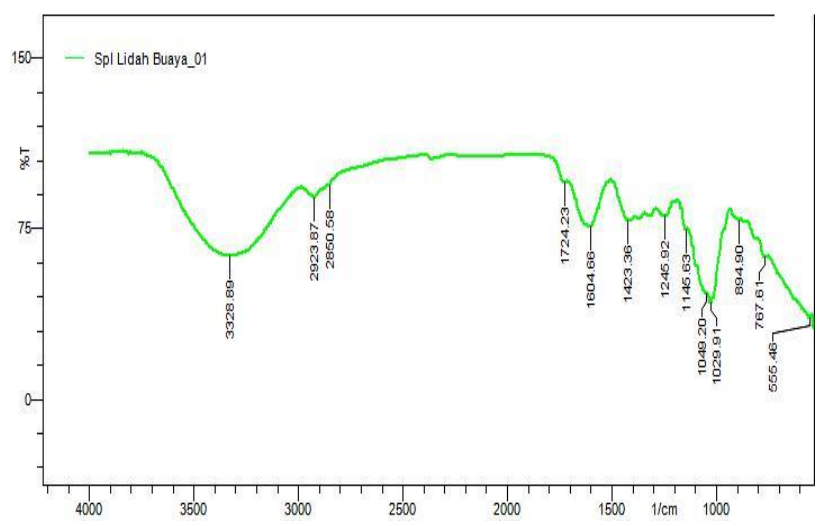

Figure 3. Aloe vera FT-IR spectrum.

Aloe vera gel produced is greenish yellow and is smooth and slimy. Aloe vera gel was then analyzed using FT-IR after going through the preparation stage. This FTIR test aims to determine the functional groups contained in the sample. The spectrum of aloe vera is presented in (Figure 3).

Edible films from each variation of anthocyanin were tested for sensitivity to acid to base solutions, namely $\mathrm{pH} 1-14$. Function of the $\mathrm{pH}$ indicator itself, which is to find out the condition of the food which will later be coated with the edible film. The color produced from the $\mathrm{pH}$ testing is presented in (table 1).

Based on table 1, it appears that the $\mathrm{pH}$ range of edible film with the addition of anthocyanin by $50 \mathrm{ml}$ shows the color of the $\mathrm{pH}$ change more clearly than the film with $25 \mathrm{ml}$ and $35 \mathrm{ml}$ anthocyanin variation. Therefore, the volume of anthocyanin that will be applied to the synthesis of edible film temperature variations, namely a volume of $50 \mathrm{ml}$.

Synthesis temperature was varied, ie between 75$90^{\circ} \mathrm{C}$ with an increase interval of $5^{\circ} \mathrm{C}$. Based on the temperature treatment of each edible film it turns out to have the same aroma, color, and taste. The edible film produced is clear purple or transparent, has a tasteless taste, and is slightly flavorful with cabbage. Based on these results, it can be said that temperature variations do not affect the results of organoleptic edible films which include aroma, color, and taste.

Film thickness is in the range $0.12-0.14 \mathrm{~mm}$. The results show that the thickest film is at a temperature of $80^{\circ} \mathrm{C}$, while the thinnest film is produced at a synthesis temperature of $75^{\circ} \mathrm{C}$. 
Table 1. Edible film color changes to $\mathrm{pH}$ changes.

\begin{tabular}{lllll}
\hline No & pH & \multicolumn{3}{c}{ Change in Film Color Based on Anthocyanin Volume } \\
\cline { 2 - 5 } & & 25 ml & 35 ml & 50 ml \\
\hline 1 & 1 & Pink & Pink (bright) & Pink (bright) \\
2 & 2 & Pink & Pink & Pink (bright) \\
3 & 3 & Pink & Pink & Pink (bright) \\
4 & 4 & Pink purple & Pink & Pink \\
5 & 5 & Pink purple & Pink & Pink Purple \\
6 & 6 & Purple & Pink purple & Purple \\
7 & 7 & Purple & Pink purple & Purple \\
8 & 8 & Purple & Purple & Purple Blue \\
9 & 9 & Purple & Purple & Dark Purple \\
10 & 10 & Purple & Purple & Dark Purple \\
11 & 11 & Purple Green & Purple & Purple Green \\
12 & 12 & Green & Purple Blue & Dark Green \\
13 & 13 & Green yellow & Green & Bright Green \\
14 & 14 & Yellow & Yellow & Yellow \\
\hline
\end{tabular}

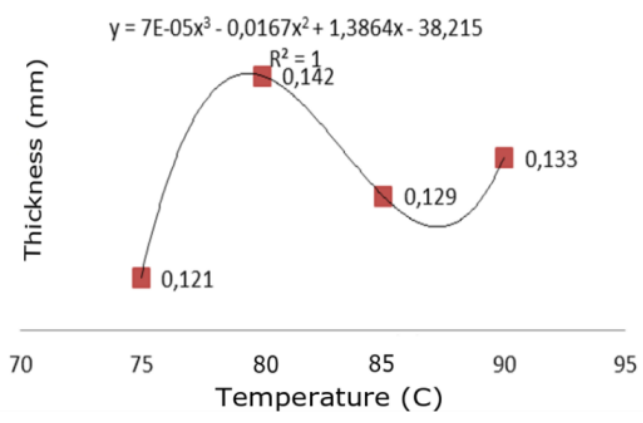

Figure 4. Graph of edible film thickness in each temperature variation.

The tensile strength values of edible film temperature variation ranged from 2.99 to $6.48 \mathrm{MPa}$ with the highest value at a temperature of $75^{\circ} \mathrm{C}$ while the lowest tensile strength, i.e. at a temperature of $80^{\circ} \mathrm{C}$ with a value of $2.99 \mathrm{MPa}$.

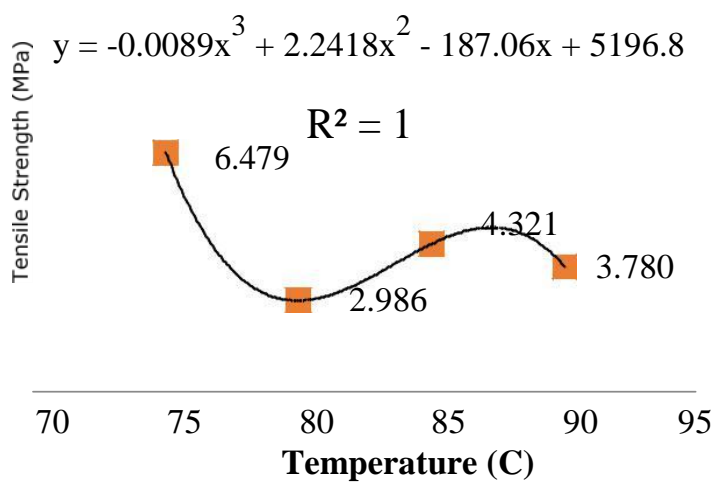

Figure 5. Graph of tensile strength of edible film temperature variations.

The highest elongation value was obtained at $85^{\circ} \mathrm{C}$ temperature synthesis with an elongation percentage of $26.66 \%$. While the lowest value, that is when the synthesis temperature is $75^{\circ} \mathrm{C}$ with an elongation percentage of $14.28 \%$. The value of elongation increases with temperature.

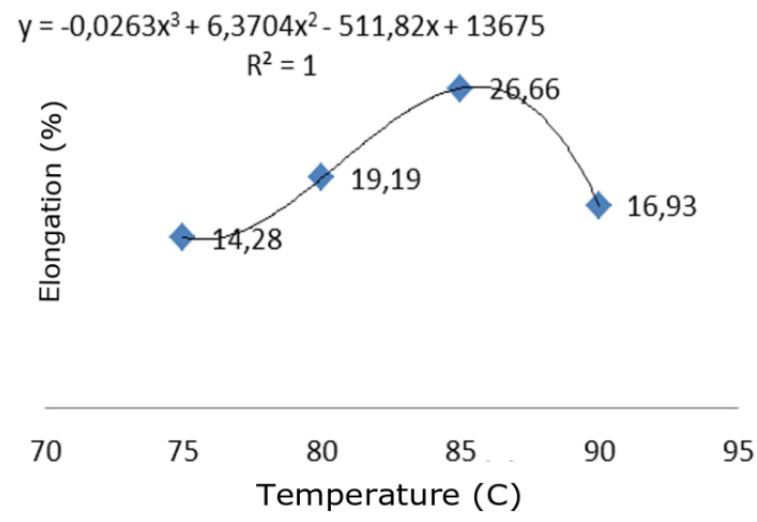

Figure 6. Percent graph of lengthening of edible film temperature variation.

The average water content of canna starch film is $13.68 \%$ (b / b). edible film with the lowest water vapor transmission rate obtained in a film with a synthesis temperature of $85{ }^{\circ} \mathrm{C}$, which is $4.72 \mathrm{~g} \mathrm{/} \mathrm{m}{ }^{2}$ hour. So, the optimum temperature can be used for the synthesis of edible films, which is $85^{\circ} \mathrm{C}$.

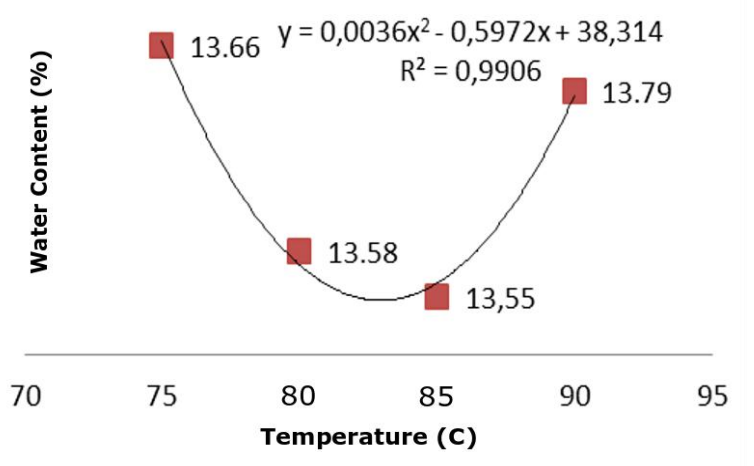

Figure7. Graph of water content in edible films.

Optimization of Anthocyanin Extract in Edible Film

The average water content of canna starch film is $13.68 \%(\mathrm{~b} / \mathrm{b})$. The effect of temperature variation on 
the water content of edible films is presented in Figure 7. In this study used canna starch and aloe vera as the film-forming material with the same concentration in each temperature variation, namely $6 \%$ canna starch and $3 \%$ aloe vera. In the film making process, starch molecules will bind water molecules into gels. The water in the material is in a bound form, both structurally and chemically in the food system, while the free water content has evaporated during the process of synthesis and drying of the film in the oven. This is what causes the water content in each temperature variation is not much different.

\section{Cluster Function Analysis with the FTIR Method}

The analysis using FT-IR aims to determine the functional groups contained in edible films. Comparison of functional groups is carried out between the spectrum of canna tubers with edible films which are only made from starch and glycerol. A comparison was then made between edible films made only from starch and glycerol with edible films which were a mixture of starch, glycerol, aloe vera, and anthocyanin from purple cabbage.

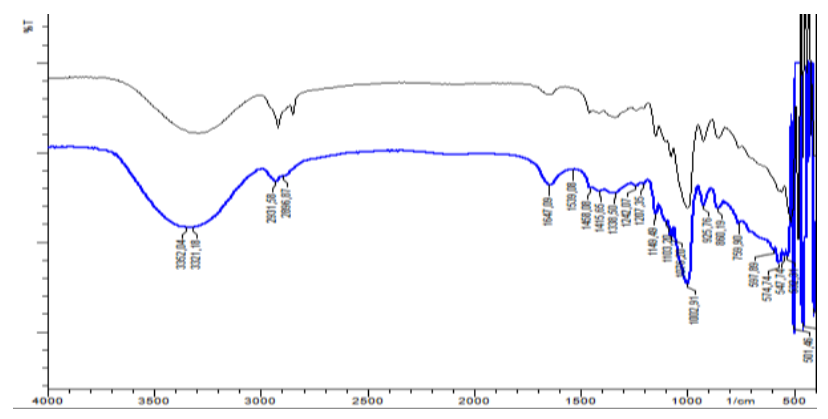

Figure 8. FT-IR spectrum of edible starch-glycerol film (a) Edible film of anthocyanin-aloe vera starch (b).

The first comparison was made to show that edible films from canna starch had been formed. The comparison between the two edible films aims to find out whether or not the addition of functional groups from edible films as a result of certain additions. In addition, this method is used to find out whether these clusters are chemically bound together or only physical interactions occur. The edible film spectrum of starchglycerol and mixtures of all ingredients can be seen in (Figure 8).

Table 2. Changing color of edible film synthesis temperature $85^{\circ} \mathrm{C}$.

\begin{tabular}{lll}
\hline No & pH & Color \\
\hline 1 & $1-3$ & Pink (Bright) \\
2 & $4-5$ & Pink \\
3 & $6-8$ & Violet \\
4 & $9-11$ & Bluish Purple \\
5 & 12 & Dark Green \\
6 & $13-14$ & Yellow \\
\hline
\end{tabular}

$\mathrm{cm}^{-1}$ which indicated the addition of $\mathrm{O}-\mathrm{H}$ and $\mathrm{C}-\mathrm{H}$ groups. Addition of $\mathrm{C}-\mathrm{O}$ groups is also seen with the new absorption at wave numbers $1539.08 \mathrm{~cm}-1$. Meanwhile, the $\mathrm{C}-\mathrm{H}$ bond in edible film without aloe vera gel was at wave number $285.58 \mathrm{~cm}^{-1}$ after addition of aloe vera changed the wave number to $2898.87 \mathrm{~cm}^{-1}$. The shift also occurs in the C-O group at wave number $999.05 \mathrm{~cm}-1$ which after addition of aloe vera gel shifts to wave number $1002.91 \mathrm{~cm}^{-1}$. Table 2 shows the results of changes in the color of the edible film after being put into an acid solution with a $\mathrm{pH}$ of 1-14. Based on changes in the color of edible film which is quite significant in each $\mathrm{pH}$ solution, it can be concluded that anthocyanin in edible film can be used as a $\mathrm{pH}$ bio-indicator.

\section{CONCLUSIONS}

Based on this research, it can be concluded that temperature is very influential on the characteristics of edible films produced, especially on the results of tensile strength, elongation, and water vapor transmission. As for organoleptic properties and water content in edible films, temperature variations did not significantly influence. Anthocyanin from purple cabbage is very effective to be used as a $\mathrm{pH}$ bioindicator on edible films because its sensitive to acids and bases can be used as a parameter for food quality.

\section{REFERENCES}

Afriyah, Y.; Widya, D. R. P.; dan Sudarma, D. W.; Addition of Aloe vera L. with Breadfruit Starch (Artocarpus communis) and Ganyong (Canna edulis Ker.) to the Characteristics of Edible film. Jurnal Pangan dan Agroindustri. Malang: Jurusan Teknologi Hasil Pertanian, FTP Universitas Brawijaya Malang. 2015. Vol. 3 No 4 Hal. 1313-1324.

Damayanti, R.; Hardeli.; Sanjaya, H. Preparasi Dye Sensitized Solar Cell (DSSC) Menggunakan Ekstrak Antosianin Ubi Jalar Ungu (Ipomoea batatas L.). Jurnal Sainstek. 2014. Vol. 6, No. 2 : 148-15.

Krochta,J. M., Baldwin, E. A. dan M. O. Nisperos-Carriedo. 1994. Edible coatings and film to improve food quality. Echnomic Publ.Co., Inc., USA.

Kusnandar, F. 2010. Kimia Pangan: Komponen Makro. Jakarta: Dyan Rakyat.

Ningwulan, M. P. S. Pembuatan Biokomposit edible film dari Gelatin/Bacterial Cellulose Microcrystal (BCMC): Variasi Konsentrasi Matriks, Filler, dan Waktu Sonikasi. Skripsi. Jakarta: Jurusan Kimia Fakultas Teknik, Universitas Indonesia, 2012.

Satrahamidjojo, H. 2013. Dasar-Dasar Spekroskopi. Yogyakarta: Gajah Mada University Press.

Skurtys O.; Acevedo C.; Pedreschi F.; Enrione J.; Osorio F.;dan Aguilera J. M. 2009. Food Hydrocolloid Edible films and Coatings. Santiago: Department of Food Science and Technology, Universidad de Santiago de Chile.

Wijoyo, A., Sinung P. F., dan Kianto, P. 2004. Karakterisasi Sifatsifat Fisik dan Mekanik Edible film Pati Ganyong (Canna edulis Kerr.). Jakarta: Universitas Indonesia.
The addition of groups from anthocyanin extract occurred at wave numbers $3352.04 \mathrm{~cm}^{-1}$ and 2931.58 
THIIS PAGE INTENTIONALL Y LEFT BLANK 